\title{
The Ross procedure is the best operation to treat aortic stenosis in young and middle-aged adults
}

\author{
Maral Ouzounian, MD, PhD, Amine Mazine, MD, MSc, and Tirone E. David, MD
}

\footnotetext{
From the Peter Munk Cardiac Centre, Division of Cardiac Surgery, Department of Surgery, University of Toronto, Toronto, Ontario, Canada.

Received for publication Oct 14, 2016; revisions received March 2, 2017; accepted for publication March 26, 2017; available ahead of print June 16, 2017

Address for reprints: Maral Ouzounian, MD, PhD, Peter Munk Cardiac Centre, 200 Elizabeth St 4N-464, Toronto M5G 2C4, Ontario, Canada (E-mail: Maral.ouzounian@uhn.ca).

J Thorac Cardiovasc Surg 2017;154:778-82

0022-5223/\$36.00

Copyright (c) 2017 by The American Association for Thoracic Surgery

http://dx.doi.org/10.1016/j.jtcvs.2017.03.156
}

When an aortic valve must be replaced, options for valve substitutes include mechanical valves, bioprosthetic valves, aortic valve homografts, and the Ross procedure (pulmonary autograft). For older patients, this choice is less critical, because bioprosthetic valves are durable in this age group. ${ }^{1,2}$ Younger patients with a longer life expectancy must be counseled carefully, because they face a higher cumulative incidence of prosthesis-related complications. When choosing a valve substitute, physicians and patients should consider the following clinically important outcomes after aortic valve replacement (AVR): survival, valve-related complications (eg, degeneration, reoperation, bleeding, thrombosis and thromboembolism), and quality of life.

\section{BIOPROSTHETIC AVR IN YOUNG AND MIDDLE-AGED PATIENTS}

Implanting bioprosthetic valves in patients before the fifth or sixth decade of life is problematic. Patient survival and bioprosthetic valve durability are known to be highly dependent on age, with worse durability ${ }^{1-4}$ and worse than expected survival ${ }^{5-7}$ following bioprosthetic AVR in younger patients. Furthermore, both randomized and retrospective studies have reported a survival advantage for mechanical valves over bioprosthetic valves in younger patients. ${ }^{8-10}$ The lifetime risk of reoperation for a 35 -year-old patient receiving a bioprosthetic valve is $63 \%$, and the risk of structural valve deterioration is even greater. $^{11}$

Despite these data, however, the use of bioprosthetic heart valves in the United States nearly doubled from $1997(42.6 \%)$ to $2006(78.4 \%) .^{12}$ This increase was seen across all age groups, although less so in younger patients. ${ }^{13}$ This trend has continued in the face of suboptimal outcomes following transcatheter valve-in-valve procedures in elderly patients, particularly those with small surgical bioprostheses, who have a 1-year mortality of $25.2 \%$ after valve-in-valve implantation. ${ }^{14}$ On the other hand, there is a paucity of data regarding transcatheter valve-in-valve younger patients. reoperation.

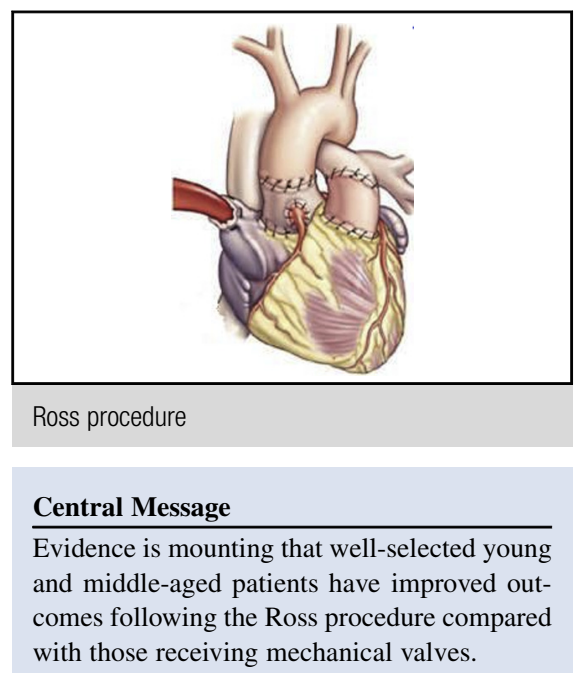

See Editorial Commentary page 783.

procedures for failed bioprosthetic surgical valves in

Although the idea that outcomes of transcatheter valvein-valve implantation will be superior in younger patients is plausible-especially if prostheses $\geq 25 \mathrm{~mm}$ are implanted at the index operation-this remains to be demonstrated rigorously. In addition, the durability of transcatheter aortic valve replacement, let alone valve-invalve implantation, remains unknown. Furthermore, although reoperative AVR may be done with reasonably low risk, ${ }^{15}$ young and middle-aged patients face multiple potential reoperations of increasing complexity. Bioprosthetic valves may be considered in young and middleaged patients with a short anticipated life expectancy or those making an informed choice regarding the risks of

\section{AORTIC VALVE HOMOGRAFTS IN YOUNG AND MIDDLE-AGED PATIENTS}

The effect of patient age on valve durability is also observed following AVR with an aortic valve homograft. In a randomized trial of the Ross procedure versus homograft root replacement in patients age $<69$ years requiring aortic valve surgery, the hazard ratio for death in the homograft group was $4.61(P=.006) .{ }^{16}$ Poor durability, limited availability, and increased complexity of reoperations have restricted the use of homografts. Nonetheless, we believe that this technique remains a useful option in patients with endocarditis and an aortic root abscess. 


\section{MECHANICAL AVR IN YOUNG AND MIDDLE-AGED PATIENTS}

Mechanical prostheses have long been the most frequently used option for AVR in younger patients. Advantages include ease of implantation with a simple, standardized technique and proven durability in a wide range of patients. All major guidelines recommend the use of mechanical valves in patients under age 60 years, although this level IIa recommendation is based on class $\mathrm{C}$ evidence. ${ }^{17,18}$ Recent studies have reported an excess mortality in young adults undergoing mechanical AVR compared with the age- and sex-matched general population. ${ }^{19}$ In fact, the younger the patient at the time of surgery, the greater the risk of mortality. ${ }^{20}$

Although mechanical valves are widely considered the most durable valve choice, rates of reoperation following mechanical AVR are not negligible. Prospective studies show a reoperation rate of $0.6 \%$ to $1.8 \%$ per year owing to valve-related complications, including valve thrombosis, pannus formation, infection, and paravalvular leak. . $^{81,22}$

The burden of anticoagulation is the main disadvantage of mechanical heart valves, with associated risks of valve thrombosis, cerebral thromboembolism, and hemorrhage. In studies with $>20$ years of follow-up, the linearized rate of thromboembolic complications or major bleeding has been between $1.1 \%$ and $4.5 \%$ per year. ${ }^{23,24}$ In one study, freedom from valve-related mortality or morbidity at 20 years after mechanical AVR was only $32 \% .^{23}$ It has been suggested that self-monitoring of oral anticoagulation may mitigate some of these risks, ${ }^{25}$ although this remains controversial. ${ }^{26}$ Similarly, newer generations of mechanical bileaflet prostheses may require less aggressive anticoagulation, ${ }^{22}$ although the rates of major bleeding $(1.48 \%$ per patient-year) and ischemic stroke $(0.74 \%$ per patientyear) remain substantial, even with lower international normalized ratio targets. ${ }^{22}$ After 20 years, $20 \%$ of patients will have experienced a stroke or episode of major bleeding. The design of more thromboresistant valves that require less or no anticoagulation is an area of active research that may ultimately change practice.

\section{ROSS PROCEDURE}

Replacement of the aortic valve with a pulmonary autograft and placement of a homograft in the pulmonary position was originally described by Ross in $1967 .{ }^{27}$ Several groups have reported excellent early results and long-term survival similar to that of the general population following the Ross procedure. ${ }^{28-30}$ Despite these excellent results, however, use of the Ross procedure remains extremely limited, with only a handful of centers worldwide offering a large volume of experience. Reece and colleagues observed a dramatic decline in use of the Ross procedure from a peak of $1.2 \%$ in 1998 through its nadir in 2010, when it accounted for only $0.09 \%$ of AVR procedures performed annually in North America. ${ }^{31}$ Only 9 centers in the Society of Thoracic Surgeons (STS) database averages 5 or more Ross procedures per year.

Although high-volume centers have published outstanding results with early mortality rates of $<1 \%,{ }^{28,32}$ some of the reluctance by surgeons to adopt the Ross procedure may be be related to the perceived increased operative risk. In a systematic review and meta-analysis, Takkenberg and colleagues $^{33}$ reported a pooled operative mortality of $3.2 \%$ in adults undergoing the Ross procedure, an unacceptable rate in this young patient population. Similarly, in a recent propensity-matched analysis from the STS database, the Ross procedure was associated with a 3 -fold higher operative mortality compared with conventional AVR $(2.7 \%$ vs $0.9 \%){ }^{31}$ In contrast, however, several experienced groups have reported operative mortality rates $<1 \%$ in patients undergoing the Ross procedure..$^{32,34-36}$ Most recently, data from a single center comparing propensity-matched patients undergoing isolated mechanical AVR and those undergoing the Ross procedure (70 patients per group) showed no early deaths and no differences in perioperative complications between the groups. ${ }^{37}$ Given the well-described inverse relationship between surgical volumes and outcomes following many different cardiac procedures, including aortic root replacement, ${ }^{38}$ it is likely that the variability in early mortality after the Ross procedure is directly related to surgeon experience and expertise. The Ross procedure should not be performed only occasionally or by surgeons not facile in root procedures.

The risk of reintervention following the Ross procedure is considered by many to be its Achilles' heel. The Rotterdam group reported a freedom from reoperation on the autograft and homograft of $57 \%$ and $93 \%$, respectively, at 13 years, leading them and others to abandon the use of the Ross procedure in adults. ${ }^{39}$ Advocates for the Ross procedure have suggested that the risk of reintervention may be mitigated by careful attention to surgical details and minute technical refinements. Supporting this position, several contemporary series have reported a rate of reintervention (for the pulmonary autograft and/or pulmonary homograft) ranging between $0.5 \%$ and $1.5 \%$ per patient-year, yielding a freedom from reintervention of $85 \%$ to $95 \%$ at 10 years. ${ }^{16,29,33,40,41}$

Several predictors of pulmonary autograft failure have been identified, including male sex, aortic/pulmonary annular mismatch, aortic annulus diameter $\geq 27 \mathrm{~mm}$, and preoperative aortic insufficiency. ${ }^{41}$ Progressive dilation of the neoaortic root with consecutive autograft insufficiency is one of the most common modes of failure following the Ross procedure. As a result, several authors have suggested prosthetic $^{42}$ or autologous ${ }^{36}$ external reinforcement of the pulmonary autograft, in an effort to mitigate the risk of late dilatation and insufficiency. 
A study from the Mayo Clinic has shown that when required, reoperations after the Ross procedure may be complex and frequently involve multiple structures. ${ }^{43}$ Although that study reported only 1 death among 56 patients who underwent reoperation at their institution - yielding a remarkably low operative mortality of $1.8 \%$ - it is worth noting that 4 additional late deaths occurred during a median follow-up of 8 months. Thus, the 1-year survival can be estimated as approximately $90 \%$, which is low for this young patient population. Compounding the issue is the potential for failure of 2 valves following the Ross procedure; however, pulmonary homograft failure is rarely a life-threatening problem, and the advent of catheter-based pulmonary valve implantation has significantly transformed the management of this problem. ${ }^{44}$

\section{COMPARATIVE STUDIES: ROSS PROCEDURE VERSUS MECHANICAL AVR}

Although several studies have reported long-term outcomes following mechanical AVR or the Ross procedure, there is a paucity of comparative data between these 2 techniques. In a small study of 80 patients, the Sievers group ${ }^{45}$ first reported superior quality of life in patients receiving a pulmonary autograft compared with those receiving a mechanical aortic valve.

The first attempt at a prospective longitudinal comparison of the Ross procedure and mechanical aortic valve replacement was reported in $2005 .^{46}$ That study, which had only limited follow-up, showed no difference in early outcomes between the 2 techniques, and a trend toward a reduced incidence of death or major complications with the use of the Ross procedure. ${ }^{46}$

In the first propensity-matched study comparing outcomes between the Ross procedure and mechanical AVR, Mokhles and colleagues ${ }^{35}$ found no difference in late survival between patients undergoing pulmonary autograft replacement and those receiving a mechanical aortic prosthesis with optimal self-management anticoagulation therapy. That study, which garnered much attention, had several important limitations. First, the 2 treatment groups underwent surgery in different centers, potentially introducing a "center effect" bias. Second, all of the mechanical AVRs were performed in a single center, whereas the Ross procedures were done in several different centers. Finally, and most importantly, the follow-up was only 5.1 years for the Ross group, compared with 6.3 years for the mechanical AVR group. A much longer follow-up is needed for this type of comparison in young patients. ${ }^{35}$

In a comparative study boasting a mean follow-up of 7.9 years in the mechanical AVR group and 9.9. years in the Ross procedure group, Andreas and colleagues ${ }^{47}$ reported superior long-term survival with the use of the Ross procedure in adult patients age $<50$ years. The Ross procedure was associated with survival equivalent to that of the age- and sex-matched general population, whereas the patients undergoing mechanical AVR showed excess mortality compared with the matched general population. However, the conclusions of that study were limited by some important baseline differences between the 2 groups, including a significantly younger age at operation for patients undergoing the Ross procedure.

In an important recent publication, Sharabiani and colleagues $^{48}$ examined early and long-term survival and freedom from reoperation in a large cohort of 1501 unselected young patients who underwent a Ross procedure or prosthetic AVR between 2000 and 2012. The authors used data extracted from the National Congenital Heart Disease Audit of the United Kingdom. This study included a subgroup of 872 young adults (age 17-40 years), of which $26 \%$ underwent a Ross procedure, $54 \%$ underwent mechanical AVR, 17\% underwent bioprosthetic AVR, and $3 \%$ underwent aortic homograft replacement. Using a Bayesian dynamic survival model and a combination of propensity score matching, restriction matching, and stochastic augmentation to match patients from the 3 main groups, the authors found the Ross procedure to be superior to mechanical valves and mechanical valves to be superior to bioprosthetic valves. The Ross procedure was the only type of AVR that resulted in survival similar to that of matched general population. The benefit of the Ross procedure compared with prosthetic AVR was most pronounced in children, but persisted in young adults.

Our group recently published the longest available comparative longitudinal study examining long-term outcomes of the Ross procedure versus mechanical AVR. ${ }^{34}$ In this propensity-matched cohort study, which included 208 pairs and had a mean follow-up of 14.2 years, early outcomes, long-term survival, and freedom from reintervention were comparable between the Ross procedure and mechanical AVR; however, the Ross procedure was associated with improved freedom from cardiac- and valve-related mortality, as well as with a significant reduction in the incidence of stroke and major bleeding at follow-up. ${ }^{34}$

\section{PATIENT SELECTION AND FUTURE DIRECTIONS}

The ideal candidate for the Ross procedure is a patient with aortic stenosis and a small or normal-sized aortic annulus. In such a patient, we can expect the pulmonary autograft to restore long-term survival to that of the general population, and to provide a durable solution with excellent quality of life, free from complications related to prosthetic valves. Evidence is mounting that these carefully selected patients have improved outcomes following the Ross procedure compared with those receiving mechanical valves. ${ }^{34,45,47,48}$

Age is an important consideration when contemplating surgical options for AVR. We believe the Ross procedure is the best operation for treating aortic stenosis in patients 
age $<50$ years. Beyond the 50-year cutoff, careful patient selection is key. In this age group (50-65 years), we reserve the Ross procedure for patients who are most likely to derive a benefit from this operation, that is, those with an anticipated life expectancy of at least 15 years, suitable anatomy, no major concomitant cardiac disease, few comorbidities, and an active lifestyle. We believe that in these carefully selected patients, the Ross procedure can be performed with no increase in perioperative morbidity and mortality. ${ }^{28}$

The Ross procedure should be given particular consideration in young and middle-aged patients contemplating pregnancy, those with high levels of physical activity, and those who either have contraindications to or prefer to avoid anticoagulation. Women of childbearing age who require AVR face significant challenges, given that all types of prosthetic valves pose major problems during pregnancy. Bioprostheses have limited durability and may degenerate more quickly during pregnancy. Mechanical valves are associated with a much higher risk of thrombosis during pregnancy, and the various options for anticoagulation all pose risks to the mother and fetus. ${ }^{49,50}$

Initial enthusiasm for the Ross procedure waned after patients began to return for complex reoperations. Decades of surgical experience and analysis of long-term outcomes have led to modifications to the technique and improvement in patient selection. An expanding body of recent literature has shown improved survival free from valve-related events in patients undergoing the Ross procedure compared with mechanical AVR. As the literature favoring the Ross procedure becomes more abundant, it becomes increasingly more difficult to simply dismiss this option for a young or middle-aged adult with aortic stenosis. Surgeons and cardiologists are responsible for reviewing the literature objectively and discussing the options for AVR in detail with their patients. A dilemma will emerge as few centers worldwide are able to offer the Ross with low perioperative risk and durable results. Of utmost importance is the need for appropriate patient selection, patient management by an experienced team, and careful prospective follow-up and reporting of all patients undergoing the Ross procedure, so that the technical aspects may be further refined. It must be emphasized that the Ross procedure should not be performed sporadically, and that a minimum annual volume of 10 to 15 of these operations-along with other aortic root procedures-is required to achieve and maintain competence.

\section{CONCLUSIONS}

Matching the patient to the most appropriate valve substitute is not always straightforward, particularly for young and middle-aged patients. Young patients often have a higher level of physical activity, are primarily concerned with quality of life, and because of their life expectancy have prolonged exposure to potential valve-related complications. The Ross procedure provides excellent freedom from death and valve-related complications in wellselected patients when performed in experienced centers.

\section{Conflict of Interest Statement}

Authors have nothing to disclose with regard to commercial support.

\section{References}

1. Bourguignon T, Bouquiaux-Stablo AL, Candolfi P, Mirza A, Loardi C, May MA et al. Very long-term outcomes of the Carpentier-Edwards Perimount valve in aortic position. Ann Thorac Surg. 2015;99:831-7.

2. David TE, Armstrong S, Maganti M. Hancock II bioprosthesis for aortic valve replacement: the gold standard of bioprosthetic valves durability? Ann Thorac Surg. 2010;90:775-81.

3. Jamieson WR, Burr LH, Miyagishima RT, Germann E, Macnab JS, Stanford E, et al. Carpentier-Edwards supra-annular aortic porcine bioprosthesis: clinical performance over 20 years. J Thorac Cardiovasc Surg. 2005;130:994-1000.

4. Mykén PS, Bech-Hansen O. A 20-year experience of 1712 patients with the Biocor porcine bioprosthesis. J Thorac Cardiovasc Surg. 2009;137:76-81.

5. Mihaljevic T, Nowicki ER, Rajeswaran J, Blackstone EH, Lagazzi L, Thomas J, et al. Survival after valve replacement for aortic stenosis: implications for decision making. J Thorac Cardiovasc Surg. 2008;135:1270-8; discussion 1278-9.

6. Bourguignon T, El Khoury R, Candolfi P, Loardi C, Mirza A, BoulangerLothion J, et al. Very long-term outcomes of the Carpentier-Edwards perimount aortic valve in patients aged 60 or younger. Ann Thorac Surg. 2015;100:853-9.

7. Forcillo J, El Hamamsy I, Stevens LM, Badrudin D, Pellerin M, Perrault LP, et al. The perimount valve in the aortic position: twenty-year experience with patients under 60 years old. Ann Thorac Surg. 2014;97:1526-32.

8. Hammermeister K, Sethi GK, Henderson WG, Grover FL, Oprian C, Rahimtoola SH. Outcomes 15 years after valve replacement with a mechanical versus a bioprosthetic valve: final report of the Veterans Affairs randomized trial. J Am Coll Cardiol. 2000;36:1152-8.

9. Weber A, Noureddine H, Englberger L, Dick F, Gahl B, Aymard T, et al. Ten-year comparison of pericardial tissue valves versus mechanical prostheses for aortic valve replacement in patients younger than 60 years of age. J Thorac Cardiovasc Surg. 2012;144:1075-83.

10. Glaser N, Jackson V, Holzmann MJ, Franco-Cereceda A, Sartipy U. Aortic valve replacement with mechanical vs. biological prostheses in patients aged 50-69 years. Eur Heart J. 2016;37:2658-67.

11. Puvimanasinghe JP, Steyerberg EW, Takkenberg JJ, Eijkemans MJ, van Herwerden LA, Bogers AJ, et al. Prognosis after aortic valve replacemen with a bioprosthesis: predictions based on meta-analysis and microsimulation. Circulation. 2001;103:1535-41.

12. Brown JM, O'Brien SM, Wu C, Sikora JA, Griffith BP, Gammie JS. Isolated aortic valve replacement in North America comprising 108,687 patients in 10 years: changes in risks, valve types, and outcomes in the Society of Thoracic Surgeons National Database. J Thorac Cardiovasc Surg. 2009;137:82-90.

13. Isaacs AJ, Shuhaiber J, Salemi A, Isom OW, Sedrakyan A. National trends in utilization and in-hospital outcomes of mechanical versus bioprosthetic aortic valve replacements. J Thorac Cardiovasc Surg. 2015;149:1262-9.e3.

14. Dvir D, Webb JG, Bleiziffer S, Pasic M, Waksman R, Kodali S, et al. Transcatheter aortic valve implantation in failed bioprosthetic surgical valves. JAMA. 2014;312:162-70.

15. Naji P, Griffin BP, Sabik JF, Kusunose K, Asfahan F, Popovic ZB, et al. Characteristics and outcomes of patients with severe bioprosthetic aortic valve stenosis undergoing redo surgical aortic valve replacement. Circulation. 2015;132: 1953-60.

16. El-Hamamsy I, Eryigit Z, Stevens LM, Sarang Z, George R, Clark L, et al. Long term outcomes after autograft versus homograft aortic root replacement in adults with aortic valve disease: a randomised controlled trial. Lancet. 2010;376 524-31.

17. Vahanian A, Alfieri O, Andreotti F, Antunes MJ, Barón-Esquivias G, Baumgartner H, et al. Guidelines on the management of valvular heart disease (version 2012). Eur Heart J. 2012;33:2451-96.

18. Nishimura RA, Otto CM, Bonow RO, Carabello BA, Erwin JP III, Guyton RA, et al. 2014 AHA/ACC guideline for the management of patients with valvular 
heart disease: a report of the American College of Cardiology/American Heart Association Task Force on Practice Guidelines. J Am Coll Cardiol. 2014;63: e57-185.

19. Bouhout I, Stevens LM, Mazine A, Poirier N, Cartier R, Demers P, et al. Longterm outcomes after elective isolated mechanical aortic valve replacement in young adults. J Thorac Cardiovasc Surg. 2014;148:1341-6.e1.

20. Kvidal P, Bergström R, Hörte LG, Ståhle E. Observed and relative survival after aortic valve replacement. J Am Coll Cardiol. 2000;35:747-56.

21. Stassano P, Di Tommaso L, Monaco M, Iorio F, Pepino P, Spampinato N, et al. Aortic valve replacement: a prospective randomized evaluation of mechanical versus biological valves in patients ages 55 to 70 years. J Am Coll Cardiol. 2009;54:1862-8.

22. Puskas J, Gerdisch M, Nichols D, Quinn R, Anderson C, Rhenman B, et al. Reduced anticoagulation after mechanical aortic valve replacement: interim results from the prospective randomized on- $\mathrm{X}$ valve anticoagulation clinical trial randomized Food and Drug Administration investigational device exemption trial. J Thorac Cardiovasc Surg. 2014;147:1202-10; discussion 1210-1.

23. Ikonomidis JS, Kratz JM, Crumbley AJ III, Stroud MR, Bradley SM, Sade RM, et al. Twenty-year experience with the St Jude Medical mechanical valve prosthesis. J Thorac Cardiovasc Surg. 2003;126:2022-31.

24. Van Nooten GJ, Caes F, François K, Van Belleghem Y, Bové T, Vandenplas G, et al. Twenty years' single-center experience with mechanical heart valves: a critical review of anticoagulation policy. J Heart Valve Dis. 2012;21:88-98.

25. Heneghan C, Ward A, Perera R, Bankhead C, Fuller A, Stevens R, et al. Selfmonitoring of oral anticoagulation: systematic review and meta-analysis of individual patient data. Lancet. 2012;379:322-34.

26. Matchar DB, Jacobson A, Dolor R, Edson R, Uyeda L, Phibbs CS, et al. Effect of home testing of international normalized ratio on clinical events. $N$ Engl J Med. 2010;363:1608-20

27. Ross DN. Replacement of aortic and mitral valves with a pulmonary autograft. Lancet. 1967;2:956-8.

28. David TE, David C, Woo A, Manlhiot C. The Ross procedure: outcomes at 20 years. J Thorac Cardiovasc Surg. 2014;147:85-93.

29. Sievers HH, Stierle U, Charitos EI, Takkenberg JJ, Hörer J, Lange R, et al. A multicentre evaluation of the autograft procedure for young patients undergoing aortic valve replacement: update on the German Ross Registry. Eur J Cardiothorac Surg. 2016;49:212-8.

30. Mastrobuoni S, de Kerchove L, Solari S, Astarci P, Poncelet A, Noirhomme P, et al. The Ross procedure in young adults: over 20 years of experience in our institution. Eur J Cardiothorac Surg. 2016;49:507-12; discussion 512-3.

31. Reece TB, Welke KF, O’Brien S, Grau-Sepulveda MV, Grover FL, Gammie JS. Rethinking the Ross procedure in adults. Ann Thorac Surg. 2014;97:175-81.

32. Sievers HH, Stierle U, Charitos EI, Hanke T, Gorski A, Misfeld M, et al. Fourteen years' experience with 501 subcoronary Ross procedures: surgical details and results. J Thorac Cardiovasc Surg. 2010;140:816-22. 822.e1-5.

33. Takkenberg JJ, Klieverik LM, Schoof PH, van Suylen RJ, van Herwerden LA, Zondervan PE, et al. The Ross procedure: a systematic review and meta-analysis. Circulation. 2009;119:222-8.

34. Mazine A, David TE, Rao V, Hickey EJ, Christie S, Manlhiot C, et al. Long-term outcomes of the Ross procedure versus mechanical aortic valve replacement: propensity-matched cohort study. Circulation. 2016;134:576-85.

35. Mokhles MM, Körtke H, Stierle U, Wagner O, Charitos EI, Bogers AJ, et al. Survival comparison of the Ross procedure and mechanical valve replacement with optimal self-management anticoagulation therapy: propensity-matched cohort study. Circulation. 2011;123:31-8.

36. Skillington PD, Mokhles MM, Takkenberg JJ, Larobina M, O'Keefe M, Wynne R, et al. The Ross procedure using autologous support of the pulmonary autograft: techniques and late results. J Thorac Cardiovasc Surg. 2015;149(2 Suppl):S46-52.

37. Bouhout I, Noly PE, Ghoneim A, Stevens LM, Cartier R, Poirier N, et al. Is the Ross procedure a riskier operation? Perioperative outcome comparison with mechanical aortic valve replacement in a propensity-matched cohort. Interact Cardiovasc Thorac Surg. 2016;24:1-7.

38. Hughes GC, Zhao Y, Rankin JS, Scarborough JE, O'Brien S, Bavaria JE, et al. Effects of institutional volumes on operative outcomes for aortic root replacement in North America. J Thorac Cardiovasc Surg. 2013;145: 166-70.

39. Klieverik LM, Takkenberg JJ, Bekkers JA, Roos-Hesselink JW, Witsenburg M, Bogers AJ. The Ross operation: a Trojan horse? Eur Heart J. 2007;28: 1993-2000.

40. Charitos EI, Stierle U, Hanke T, Schmidtke C, Sievers HH, Richardt D. Longterm results of 203 young and middle-aged patients with more than 10 years of follow-up after the original subcoronary Ross operation. Ann Thorac Surg. 2012;93:495-502.

41. David TE, Woo A, Armstrong S, Maganti M. When is the Ross operation a good option to treat aortic valve disease? J Thorac Cardiovasc Surg. 2010;139:68-73; discussion 73-5.

42. Carrel T, Kadner A. Long-term clinical and imaging follow-up after reinforced pulmonary autograft Ross procedure. Semin Thorac Cardiovasc Surg Pediatr Card Surg Annu. 2016;19:59-62.

43. Stulak JM, Burkhart HM, Sundt TM III, Connolly HM, Suri RM, Schaff HV, et al. Spectrum and outcome of reoperations after the Ross procedure. Circulation. 2010;122:1153-8.

44. Gillespie MJ, McElhinney DB, Kreutzer J, Hellenbrand WE, El-Said H, Ewert P, et al. Transcatheter pulmonary valve replacement for right ventricular outflow tract conduit dysfunction after the Ross procedure. Ann Thorac Surg. 2015; 100:996-1002; discussion 1002-3.

45. Nötzold A, Hüppe M, Schmidtke C, Blömer P, Uhlig T, Sievers HH. Quality of life in aortic valve replacement: pulmonary autografts versus mechanical prostheses. J Am Coll Cardiol. 2001;37:1963-6.

46. Concha M, Aranda PJ, Casares J, Merino C, Alados P, Muñoz I, et al. Prospective evaluation of aortic valve replacement in young adults and middle-aged patients: mechanical prosthesis versus pulmonary autograft. J Heart Valve Dis. 2005; 14 : 40-6.

47. Andreas M, Wiedemann D, Seebacher G, Rath C, Aref T, Rosenhek R, et al. The Ross procedure offers excellent survival compared with mechanical aortic valve replacement in a real-world setting. Eur J Cardiothorac Surg. 2014;46:409-13; discussion 413-4.

48. Sharabiani MT, Dorobantu DM, Mahani AS, Turner M, Peter Tometzki AJ, Angelini GD, et al. Aortic valve replacement and the Ross operation in children and young adults. J Am Coll Cardiol. 2016;67:2858-70.

49. Bouhout I, Poirier N, Mazine A, Dore A, Mercier LA, Leduc L, et al. Cardiac, obstetric, and fetal outcomes during pregnancy after biological or mechanical aortic valve replacement. Can J Cardiol. 2014;30:801-7.

50. Hung L, Rahimtoola SH. Prosthetic heart valves and pregnancy. Circulation. 2003;107:1240-6. 